\section{Commentary: Cath lab 911}

\author{
Connor P. McDonald, MD, and Dawn S. Hui, MD
}

The advent of angioplasty beginning in the 1980s has made cardiac catherization a daily and important tool for treatment in cardiovascular disease, with more than 1,000,000 catheterizations performed annually in the United States. Major complication rates are less than $1 \%$, and risk of mortality is $\sim 0.05 \%$ to $1 \%{ }^{1}$ When examining catheter-related complications, it is important to decipher between diagnostic and therapeutic cardiac catheterization procedures. The rate and severity of such complications are often greater in therapeutic procedures, owing to the use of larger sheaths, stiffer guidewires, and manipulation within coronary vessels.

While there remains an overall paucity of data on surgical intervention following cardiac catheterization-related complications, the most well-studied complication remains emergency coronary artery bypass graft (CABG) surgery following failed percutaneous coronary intervention. Indications for emergent CABG include ongoing ischemia, coronary artery perforation, rupture, threated occlusion, hemodynamic compromise, and tamponade. ${ }^{2}$ In 2 institutional analyses of $>43,000$ patients, the advent of coronary stents decreased the rate of emergency CABG from $1.5 \%$ $3.0 \%$ to $<0.7 \%$, but the associated mortality remained high at $10 \%$ to $15 \%$. $^{3,4}$

In this issue of JTCVS Techniques, Waterford and colleagues $^{5}$ present a case that brings to light the specific complication of burr entrapment that cardiac surgeons may face during their career. Atherectomy is associated with greater coronary artery perforation rates of $1.0 \%$ to $2.0 \%,{ }^{6-8}$ often attributed to oversizing and forceful advancement of the burr. ${ }^{8}$ The incidence of burr entrapment in a recent series ranged from $0.5 \%$ to $1.0 \%{ }^{9,10}$ Successful management of this rare complication is often successfully

\footnotetext{
From the Department of Cardiothoracic Surgery, University of Texas Health Science Center at San Antonio, San Antonio, Tex.

Disclosures: The authors reported no conflicts of interest.

The Journal policy requires editors and reviewers to disclose conflicts of interest and to decline handling or reviewing manuscripts for which they may have a conflict of interest. The editors and reviewers of this article have no conflicts of interest.

Received for publication March 29, 2021; revisions received March 29, 2021; accepted for publication March 31, 2021; available ahead of print April 3, 2021.

Address for reprints: Dawn S. Hui, MD, Department of Cardiothoracic Surgery, University of Texas Health Science Center at San Antonio, 7703 Floyd Curl Dr, San Antonio, TX 78258 (E-mail: dawn.hui@gmail.com).

JTCVS Techniques 2021;7:159-60

2666-2507

Copyright (C) 2021 The Authors. Published by Elsevier Inc. on behalf of The American Association for Thoracic Surgery. This is an open access article under the CC BY-NCND license (http://creativecommons.org/licenses/by-nc-nd/4.0/).

https://doi.org/10.1016/j.xjtc.2021.03.033
}

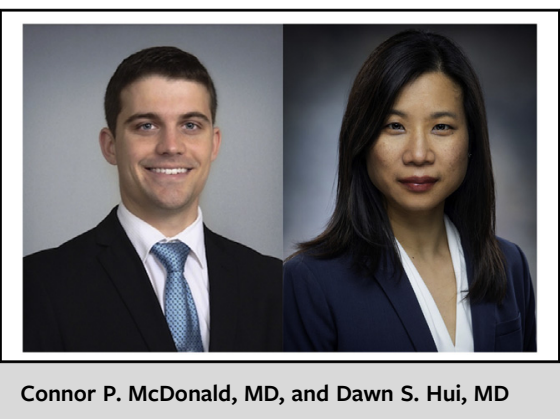

\begin{abstract}
CENTRAL MESSAGE
The sheer volume of cardiac catheterization procedures mandates that surgeons be prepared to treat rare complications, combining technique and judgment gained from the operating room and cath lab.
\end{abstract}

treated with conservative techniques, including relief of tension and removal of slow retrograde traction to relieve the entrapment. If unsuccessful, catheter-based solutions are often attempted, such as balloon dilation proximal to entrapment site or deep guide catheter with subintimal tracking and re-entry with balloon dilation adjacent to entrapment. ${ }^{11-14}$

In Waterford and colleagues' report, the principles of management discussed are valuable tools in the armamentarium of the surgeon who is faced with this difficult situation. The goals of the operation are several-fold - to remove the burr, to mitigate any coronary damage already caused, and to treat any pathology causing ischemia, whether it is be native disease, a foreign body, or iatrogenic damage. Fortunately, in the case presented, the patient was stable, and the burr was easily removed through a distal arteriotomy, with a guidewire perforation providing a visual guide to the area of concern. However, good outcomes may be more exigent in cases of hemodynamic instability, ongoing ischemia, or coronary rupture. Continued difficulty in removing a burr entrapped in a stent may pose an additional challenge. Thus, the surgeon must be prepared to act expeditiously and judiciously, balancing how to treat harm already caused with limiting the degree to which further harm is incurred.

\section{References}

1. Manda YR, Baradhi KM. Cardiac catheterization risks and complications. In: StatPearls. Treasure Island (FL): StatPearls Publishing; 2021:1-6. 
2. Eagle KA, Guyton RA, Davidoff R, Edwards FH, Ewy GA, Gardner TJ, et al; American College of Cardiology, American Heart Association. ACC/AHA 2004 guideline update for coronary artery bypass graft surgery: a report of the American College of Cardiology/American Heart Association task force on practice guidelines (committee to update the 1999 guidelines for coronary artery bypass graft surgery). Circulation. 2004;110:e340.

3. Yang EH, Gumina RJ, Lennon RJ, Holmes DR Jr, Rihal CS, Singh M. Emergency coronary artery bypass surgery for percutaneous coronary interventions: changes in the incidence, clinical characteristics, and indications from 1979 to 2003. J Am Coll Cardiol. 2005;46:2004.

4. Seshadri N, Whitlow PL, Acharya N, Houghtaling P, Blackstone EH, Ellis SG. Emergency coronary artery bypass surgery in the contemporary percutaneous coronary intervention era. Circulation. 2002;106:2346.

5. Waterford SD, Suleman UJ, Sharma S, Filsoufi F. Surgical removal of rotational atherectomy device. J Thorac Cardiovasc Surg Tech. 2021;7:153-6.

6. Holmes DR Jr, Holubkov R, Vlietstra RE, Kelsey SF, Reeder GS, Dorros G, et al Comparison of complications during percutaneous transluminal coronary angioplasty from 1977 to 1981 and from 1985 to 1986: the National Heart, Lung, and Blood Institute Percutaneous Transluminal Coronary Angioplasty Registry. J Am Coll Cardiol. 1988;12:1149.
7. Ellis SG, Ajluni S, Arnold AZ, Popma JJ, Bittl JA, Eigler NL, et al. Increased coronary perforation in the new device era. Incidence, classification, management, and outcome. Circulation. 1994;90:2725.

8. Gupta T, Weinreich M, Greenberg M, Colombo A, Latib A. Rotation atherectomy: a contemporary appraisal. Interv Cardiol. 2019;14:182-9.

9. Tomey M, Kini A, Sharma S. Current status of rotational atherectomy. JACC Cardiovasc Interv. 2014; 7:345-53.

10. Sharma K, Tomey M, Teirstein P, Kini AS, Reitman AB, Lee AC, et al. North American expert review of rotational atherectomy. Circ Cardiovasc Interv. 2019;12:e007448.

11. Tanaka Y, Saito S. Successful retrieval of a firmly stuck rotablator burr by using a modified STAR technique. Catheter Cardiovasc Interv. 2016;87:749-56.

12. Cunnington M, Egred M. GuideLiner, a child-in-a-mother catheter for successful retrieval of an entrapped rotablator burr. Catheter Cardiovasc Interv. 2012;79: 271-3.

13. Sakakura K, Ako J, Momomura S. Successful removal of an entrapped rotablation burr by extracting drive shaft sheath followed by balloon dilatation. Catheter Cardiovasc Interv. 2011;78:567-70.

14. Sulimov D, Abdel-Wahab M, Toelg R, Kassner G, Geist V, Richardt G. Stuck rotablator: the nightmare of rotational atherectomy. EuroIntervention. 2013;9:251-8. 